\title{
Meteorological observations on the northern Chilean coast during VOCALS-REx
}

\author{
J. A. Rutllant ${ }^{1,2}$, R. C. Muñoz ${ }^{1}$, and R. D. Garreaud ${ }^{1,3}$ \\ ${ }^{1}$ Department of Geophysics, University of Chile, Santiago, Chile \\ ${ }^{2}$ Centro de Estudios Avanzados en Zonas Áridas (CEAZA), La Serena, Chile \\ ${ }^{3}$ Center for Climate and Resilience Research $(\mathrm{CR})^{2}$, Santiago, Chile \\ Correspondence to: R. C. Muñoz (rmunoz@dgf.uchile.cl) \\ Received: 31 July 2012 - Published in Atmos. Chem. Phys. Discuss.: 3 September 2012 \\ Revised: 30 January 2013 - Accepted: 27 February 2013 - Published: 25 March 2013
}

\begin{abstract}
Surface coastal observations from two automatic weather stations at Paposo $\left(\sim 25^{\circ} \mathrm{S}\right)$ and radiosonde observations at Paposo and Iquique $\left(\sim 20^{\circ} \mathrm{S}\right)$ were carried out during VOCALS-REx (VAMOS Ocean-Cloud-AtmosphereLand Study Regional Experiment). Within the coastal marine boundary layer (MBL), sea-land breezes are superimposed on the prevailing southerlies, resulting in light northeasterly winds from midnight to early morning and strong southwesterlies in the afternoon. The prevailing northerlies above the MBL and below the top of the Andes are modulated by the onshore-offshore (zonal) flow forced by the diurnal cycle of surface heating/cooling along the western slope of the Andes. The daytime phase of this diurnal cycle is consistent with an enhanced afternoon coastal subsidence manifested in afternoon warming near the top of the subsidence inversion $(\sim 1.8 \mathrm{~K}$ at $800 \mathrm{hPa})$, lowering $(\sim 130 \mathrm{~m})$ of its base (top of the MBL), and clearing of coastal Sc (stratocumulus) clouds. Results from a numerical simulation of the atmospheric circulation in a mean zonal cross section over the study area capture the afternoon zonal wind divergence and resulting subsidence of about $2 \mathrm{~cm} \mathrm{~s}^{-1}$ along a narrow $(\sim 10 \mathrm{~km})$ coastal strip maximizing at around $800 \mathrm{hPa}$. Dayto-day variability in the MBL depth during VOCALS-REx shows sub-synoptic oscillations, aside from two major disruptions in connection with a deep trough and a cutoff low, as described elsewhere. These oscillations are phase-locked to those in sea-level pressure and afternoon alongshore southerlies, as found in connection with coastal lows farther south.

From 24-h forward trajectories issued from significant points at the coast and inland at the extremes of the diurnal cycle, it can be concluded that the strong mean daytime
\end{abstract}

Andean pumping prevents any possibility of continental sulfur sources from reaching the free troposphere above the Sc cloud deck in at least a one-day timescale, under mean conditions. Conversely, coastal sources could contribute with sulfur aerosols preferentially in the morning, provided that the weak daytime inland flow becomes partially blocked by the coastal terrain.

\section{Introduction}

The international VOCALS-REx (VAMOS Ocean-CloudAtmosphere-Land Study Regional Experiment; 15 October14 November 2008) was aimed at studying interaction processes between ocean, atmosphere, cloud and land in the southeastern Pacific, along and off the coasts of southern Peru and northern Chile (Wood et al., 2011). Over this region, dominated by the SE Pacific subtropical anticyclone with a marked subsidence temperature inversion at about $1000 \mathrm{~m}$ a.m.s.l., austral spring is the season of maximum intensity of the anticyclone, featuring the most extensive and persistent stratocumulus ( $\mathrm{Sc}$ ) cloud deck topping the marine boundary layer (MBL) under the inversion (e.g., Painemal et al., 2010). It is well known that these clouds play a key role in the global radiation budget as well as in the regional climate along the coast (e.g., Bretherton et al., 2004).

A central aspect of VOCALS-REx was the quantitative assessment of the role of oxidized sulfur aerosols acting as Sc condensation nuclei over the coastal ocean, particularly along southern Peru and northern Chile, resulting in high cloud droplet number concentrations (Wood et al., 2011). 

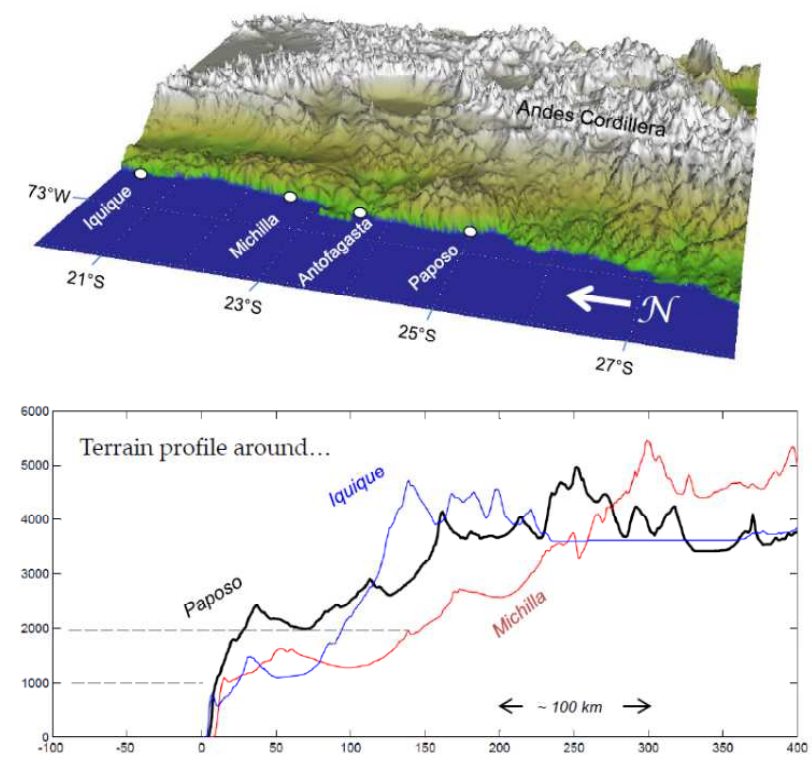

Fig. 1. Location of radiosonde observations referred to in the text (top panel) and topographic zonal (cross shore) cross sections at the indicated sites (bottom panel). Elevation heights expressed in meters above sea level.

Relationships between aerosol composition and transport in the polluted near-shore region and in the cleaner area offshore have been discussed in Allen et al. (2011), Zheng et al. (2011), Yang et al. (2012) and Saide et al. (2012). There, long-range eastward air mass transport is connected with the subtropical jet stream. The near-shore polluted area features higher frequency variability (i.e., diurnal and subsynoptic) both within the MBL (i.e., coastal lows, coastal upwelling), where alongshore transport prevails, and in the FT (free troposphere) above, in connection with the daytime Andean pumping.

Natural sulfur emissions that originate both at the ocean surface (i.e., dimethyl sulphide: DMS) and far inland (volcanoes) do not seem to be relevant within the coastal MBL (Chand et al., 2010; Wood et al., 2011). Conversely, since sulphate aerosols constitute a significant portion of submicron species measured at the coastal site of Paposo ( $\sim 25.1^{\circ} \mathrm{S}$; Chand et al., 2010) and dominate within the MBL over the VOCALS-REx study area (Allen et al., 2011), the likely contributions from a few thermoelectric power plants below the subsidence inversion seem relevant. Above the MBL (i.e., 2-4 km) over the western slope of the Andes, sulfur dioxide emissions (e.g., Chuquicamata copper smelter) may play an important role at least during easterly-wind episodes and subsequent entrainment into the Sc cloud layer (e.g., Huneeus et al., 2006; Allen et al., 2011; Spak et al., 2010; Saide et al., 2012).

Given the importance of the meteorological forcing in generating internal variability in the Sc cloud cover (e.g., Rahn and Garreaud, 2010b; Sun et al., 2011), it becomes essential from a meteorological perspective to understand the transport processes from these relevant emission sources, within and above the MBL, towards the cloud deck during VOCALSREx. This amounts to characterizing the mean air flow and air temperature changes along the coast in the scale of hours (diurnal cycles) in the lower troposphere, which is basically controlled by the diurnal cycle of radiative warming/cooling over the coastal and Atacama deserts, and along the western slope of the Andes (e.g., Rutllant et al., 2003).

Setting the stage for the atmospheric circulation at the eastern flank of the subtropical anticyclone, surface equatorwards winds derived from QuikScat (Quick Scatterometer) data feature a triangle of lower speeds between $\sim 16$ and $27^{\circ} \mathrm{S}$, encompassing a large portion of the VOCALSREx coastal area (e.g., Muñoz, 2008; his Fig. 1a. Garreaud et al., 2011; their Fig. 1), with decreasing speeds towards the coast, particularly in austral winter and spring (not shown). However, winds recorded at coastal surface stations feature large alongshore variability influenced by the coastal shape (e.g., Figueroa and Moffat, 2000). Particularly strong afternoon winds occur near capes and points in connection with coastal upwelling areas (Garreaud et al., 2011; their Fig. 3 and references therein). Next to them, lower surface winds and high low-cloud persistence are usually found (e.g., Paposo, just north of the Tal-Tal upwelling area).

Advances towards understanding the basic features of the regional circulation across a zonal transect in northern Chile at $\sim 23^{\circ} \mathrm{S}$ were attempted during the DICLIMA (Climate Dynamics of the Antofagasta Region) experiment (Rutllant et al., 1998, 2003), in which strong diurnal cycles in temperature and winds were identified, spanning most of the troposphere below the top of the Andes. Diurnal cycles in zonal winds above the subsidence inversion alternate from daytime eastward (inland) flow to nighttime westward (seaward) flow in the lower layers, with their corresponding return flows just above them.

Although the austral spring synoptic-scale signal associated with midlatitude weather disturbances is largely overridden by the near-shore diurnal cycles along the study area, observed day-to-day variability in the coastal MBL depth still results in significant changes in coastal wind and cloudiness regimes (Rutllant et al., 1998, 2003; Muñoz et al., 2011). In particular, synoptically-forced episodic easterly-wind events at $\sim 23^{\circ} \mathrm{S}$, occurring about four to eight times per year, were documented by Huneeus et al. (2006). For a particular event, these authors performed a numerical simulation in which the associated transport and deposition of sulfur aerosols from copper-smelter emissions in the area resulted qualitatively consistent with anomalies in satellite-derived Sc cloud droplet number concentrations. Synoptic weather patterns associated with these easterly wind events were found similar to those characterizing the onset of coastal lows in central Chile (Garreaud et al., 2002).

This paper aims at characterizing, through observational analysis and model simulation diagnostics, the diurnal cycles 

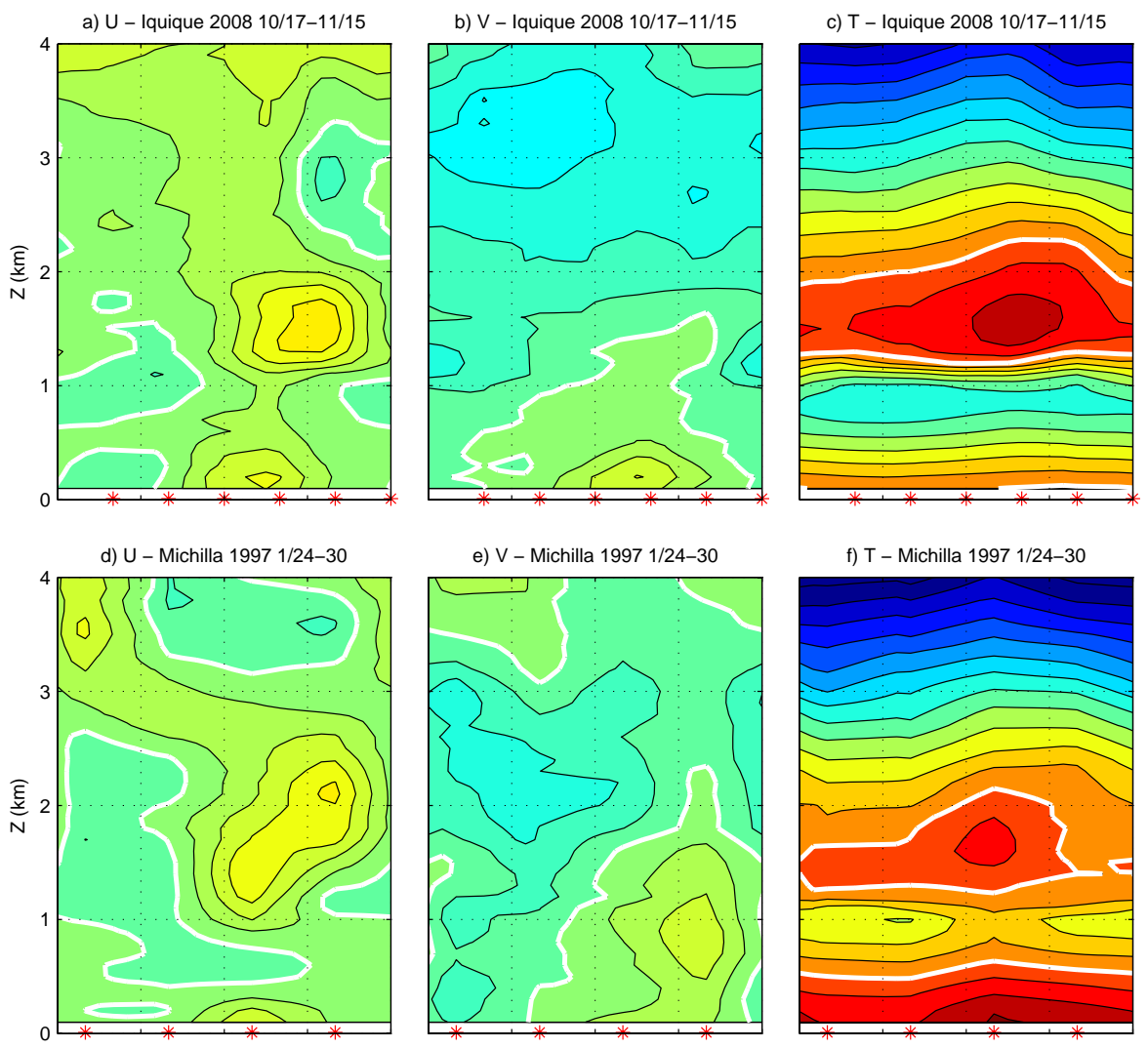

e) V - Michilla 1997 1/24-30
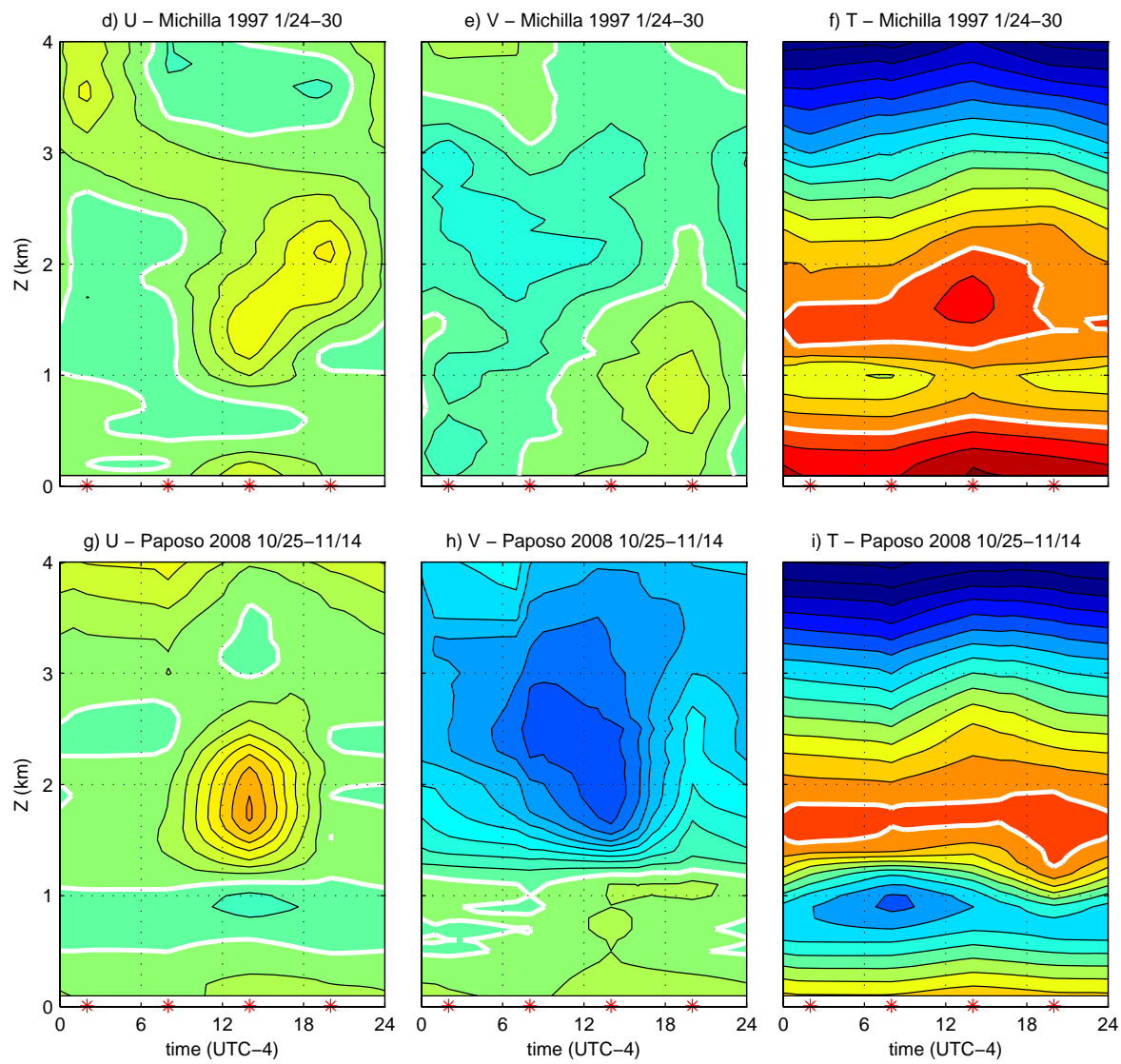

Fig. 2. Mean diurnal cycles from radiosonde data at Iquique and Paposo during VOCALS-REx, and from Michilla radiosondes in January 1997. Left panels: zonal wind component $\left(1 \mathrm{~m} \mathrm{~s}^{-1}\right.$ contours; white contour is $\left.0 \mathrm{~m} \mathrm{~s}^{-1}\right)$. Center panels: id. for the meridional wind component. Right panels: air temperature $\left(1^{\circ} \mathrm{C}\right.$ contours, white contour is $\left.17^{\circ} \mathrm{C}\right)$. Red stars in the time axis represent observing hours. Averaging period for Paposo ranges from 25 October to 14 November, in which only five 02:00 LT (UTC-4) radiosoundings are available.

of the mean atmospheric circulation both within and above the MBL and along the Andean slope up to $4000 \mathrm{~m}$ a.m.s.l., in order to assess its mean transport effectiveness. Along this coastal strip ( $\sim 50 \mathrm{~km}$ wide), modified local sea breezes (Muñoz, 2008), coastal upwelling and high Sc cloud cover variability are observed (e.g., Garreaud et al., 2011). Day-today variability of the MBL depth, and concurrent meteorological variables, during VOCALS-REx is also addressed.
The paper is organized as follows. After describing the ground site, the surface and upper-air meteorological data collected during the experiment and the model setup for the numerical simulation in Sect. 2, the main features of the diurnal cycles and their numerical simulation are presented in Sect. 3, including also a characterization of the day-today variability of the MBL depth in response to synoptic- 

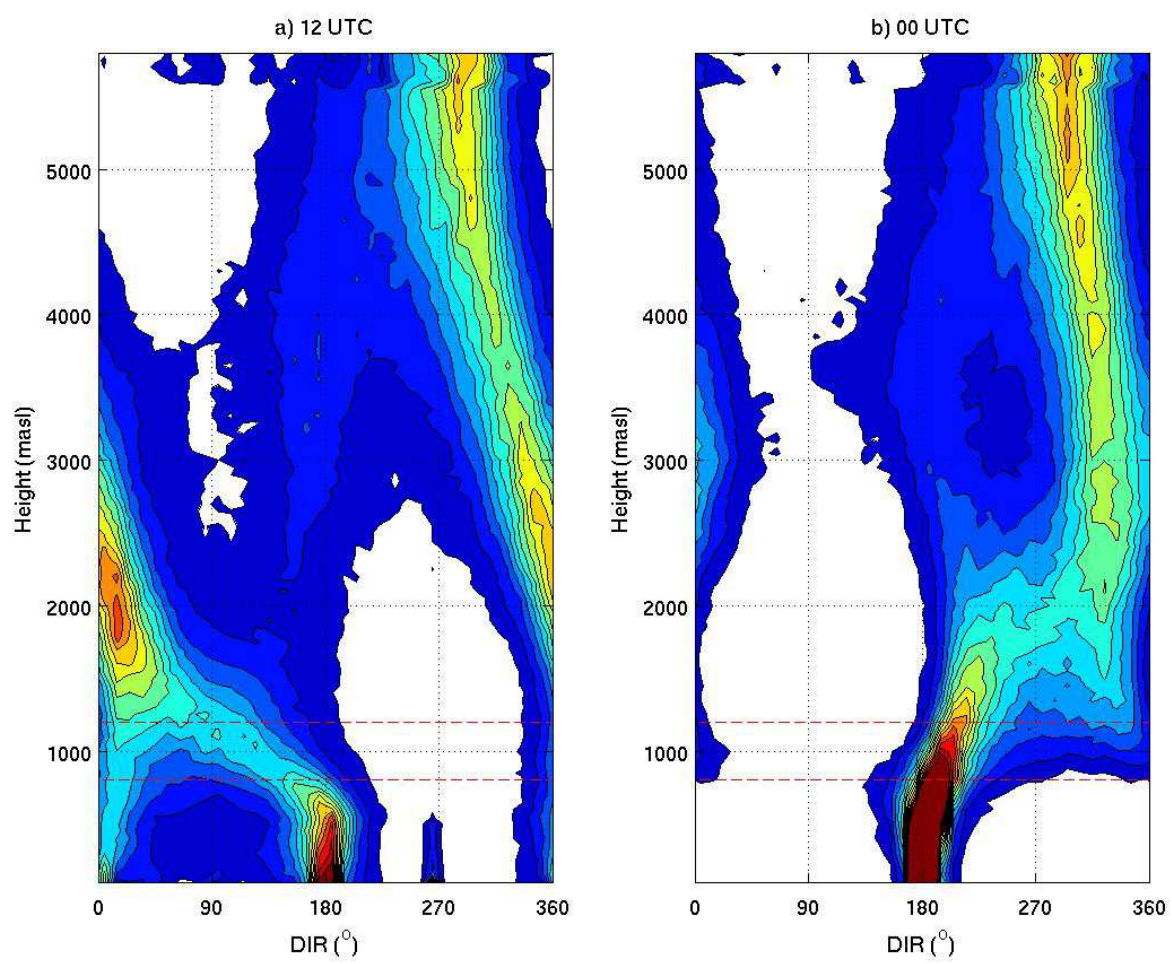

Fig. 3. Mean frequency distribution of wind directions at Antofagasta (Cerro Moreno Airport) at (a) 12:00 UTC (08:00 LT) and (b) 00:00 UTC (20:00 LT) as a function of standard height. A total of 5707 days in the 1961-1987 period was considered in the analysis for which 2 daily upper-air observations were available. Contours are shown from $1 \%$ to $15 \%$ every $1 \%$. Horizontal dashed lines mark the height region where the subsidence inversion base is generally located at this site according to Muñoz et al. (2011).

scale weather conditions during VOCALS-REx. A summary is presented in Sect. 4.

\section{Data and methods}

Between 15 October and 14 November 2008, land-based meteorological observations were carried out at Paposo $\left(\sim 25.1^{\circ} \mathrm{S}\right)$, in the southern part of the VOCALS-REx area (Fig. 1). Surface meteorological observations were averaged every $5 \mathrm{~min}$ through standard tripod-mounted Campbell automatic weather stations at Paposo Bajo (PB), near sea-shore, and at Paposo Alto (PA) located on a coastal flat just above $\mathrm{PB}$ at $\sim 700 \mathrm{~m}$ a.m.s.l. (Table 1). Wind sensors were located at $\sim 4 \mathrm{~m}$ above the ground on top of the tripod. PA was selected as the land site for "in-cloud" surface-based observations during VOCALS-REx. In fact, not only is PA located near the top of the MBL, but it is a place where Sc clouds tend to persist due to the coastline shape (i.e., embayment between Point Pasallaves $\left(\sim 24.8^{\circ} \mathrm{S}\right)$ to the north of Paposo and Point San Pedro $\left(\sim 25.4^{\circ} \mathrm{S}\right)$ to the south), as depicted in a low-cloud climatology along the coast of north-central Chile (González et al., 2007) and manifested in a dense garden of native shrubs growing along the windward side of the coastal escarpment.
Table 1. Sensors and equipment for PA and PB Campbell Scientific Inc. automatic weather stations, including functioning periods.

\begin{tabular}{|c|c|c|}
\hline Name/Make & Model at PA & Model at PB \\
\hline $\begin{array}{l}\text { Pyranometer } \\
\text { Apogee }\end{array}$ & PYR-P & PYR-P \\
\hline $\begin{array}{l}\text { Net radiometer } \\
\text { Kipp\&Zonen }\end{array}$ & NR Lite & NR Lite \\
\hline Barometer Vaisala & РTB 101B & РTB 101B \\
\hline $\begin{array}{l}\text { Anemometer RM } \\
\text { Young }\end{array}$ & 03001 Wind Sentry & 03001 Wind Sentry \\
\hline T/HR Vaisala & HMP 45C & HMP 45AC \\
\hline Data logger CSI & CR10X-2 Mega & CR10X \\
\hline Installed/Retired & 23 Jul/15 Nov 2008 & 13 Oct/16 Nov 2008 \\
\hline
\end{tabular}

Local upper-air observations consisted of Vaisala RS80$15 \mathrm{G}$ radiosonde launchings at $\mathrm{PB}$. In order to expand the latitudinal and temporal representativeness of our analysis we include also results for upper-air observations performed at Iquique and Cerro Moreno (CM: Antofagasta airport) during VOCALS-REx, as well as radiosoundings launched at Michilla $\left(\sim 22.7^{\circ} \mathrm{S}\right)$ in January 1997 (DICLIMA Experiment, Rutllant et al., 1998, 2003), during neutral ENSO (El Niño Southern Oscillation) conditions. Table 2 shows the times and periods of these available coastal upper-air observations. Figure 1 depicts the location of the sites along with 
Table 2. Times of coastal upper air observations during VOCALSREx and Michilla, 1997.

\begin{tabular}{lll}
\hline Station & Period & UTC Times \\
\hline Paposo & 17 Oct-15 Nov 2008 & $00,06^{\mathrm{a}}, 12,18^{\mathrm{b}}$ \\
Iquique & 15 Oct-15 Nov 2008 & $00,04,08,12,16,20$ \\
Antofagasta & 16 Oct-16 Nov 2008 & $00,12^{\mathrm{c}}$ \\
Michilla & 24-30 Jan 1997 & $00,06,12,18$ \\
\hline
\end{tabular}

a 06:00 UTC soundings at Paposo are available starting on 11 Nov 2008.

b 18:00 UTC soundings at Paposo are available starting on 24 Oct 2008.

c 12:00 UTC soundings at Antofagasta are operational. 00:00 UTC soundings are limited to VOCALS-REx period.

three W-E topographic cross-sections spanning the study area. There, the coastal cliff and mountain ranges, with an average elevation exceeding $1000 \mathrm{~m}$, confine the coastal MBL and associated Sc clouds on its top, to a narrow $(\sim 10 \mathrm{~km}$ wide) coastal-desert strip. The Andean western slope is particularly steep and uniform inland of Iquique.

To supplement the observational results, we performed a short-term, high-resolution numerical simulation using the WRF (Weather Research and Forecasting) model. The model was initialized at 18:00 UTC, 31 October 2008, and integrated continuously for the next four days. We choose this period within VOCALS-REx because it featured stable synoptic conditions associated with ridging in the middle troposphere (e.g., Rahn and Garreaud, 2010b), so that average diurnal cycles are meaningful. Results presented here are taken from the inner domain with a horizontal grid spacing of 2 $\mathrm{km}$ and $44 \sigma$ levels in the vertical with telescoping resolution toward the surface. The inner domain, spanning a rectangular region from $18-26^{\circ} \mathrm{S}$ and $77-66^{\circ} \mathrm{W}$, was embedded in a larger domain with 6-km horizontal resolution. Parameters used for the run include the Thompson microphysics scheme, rapid radiative transfer model and Dudhia radiation schemes, Monin-Obukhov (Janjic) surface scheme, Pleim land-surface model, Mellor-Yamada-Janjic boundary layer scheme, Betts-Miller-Janjic cumulus scheme, second-order turbulence and mixing, and a horizontal Smagorinsky firstorder closure eddy coefficient.

Results from the model simulation include validation against radiosonde observations at Iquique and Paposo, 24-h 3-D forward trajectories, and diagnostics of the mean diurnal cycle in heating/cooling within the subsidence inversion. The authors are well aware of the deficiencies of WRF, as well as of other regional numerical models, in simulating the MBL in the near-shore area. Indeed, several works have shown that the modeled MBL is substantially shallower (by a factor 2) than observed [MM5 (Mesoscale Model; Garreaud and Muñoz, 2005), WRF (Rahn and Garreaud, 2010a), COAMPS (Coupled Ocean/Atmosphere Mesoscale Prediction System; Wang et al., 2011), and MetUM (Met Office Unified Model; Abel et al., 2010)], which hinders the model capability of simulating the coastal cloud deck. The problem is only slightly attenuated by increasing horizontal or vertical resolution. Nevertheless, here we focus on the regionalscale circulation above the MBL, where, as we show later, the WRF simulation was able to resolve the diurnally varying, topographically-forced wind system.

\section{Results}

\subsection{Mean diurnal cycles}

Diurnal cycles of surface winds and MBL structure over the subtropical southeast Pacific have been recently described and analyzed in Muñoz (2008) and in Rahn and Garreaud (2010a), respectively. Figure 2 represents mean diurnal cycles of vertical profiles of wind and air temperature for the upper-air measuring sites during VOCALS-REx (i.e., Paposo and Iquique), together with those from Michilla (January 1997). Above the MBL, and except for minor differences between them, an inland flow $(U>0)$ is observed at around $1000-2500 \mathrm{~m}$, peaking at $\sim 1700 \mathrm{~m}$ altitude and centered at 18:00 LT (Local Time; Coordinated Universal Time: UTC4) at Iquique and Michilla, but at $\sim 14: 00$ LT at Paposo. Reasons for this phase shift in the timing of the maximum diurnal upslope flow are not yet clear. A weak seaward return flow appears around $3000 \mathrm{~m}$ altitude. The nocturnal phase of this cycle, much less intense than the daytime one, is observed at about the same altitude range, peaking around 08:00 LT. These results are generally consistent with those from previous studies (Rutllant et al., 2003).

Within the MBL, Fig. 2 shows that south-southwesterly winds peak between 16:00 and 18:00 LT, alternating with weaker northeasterlies at dawn at Iquique and partially at Michilla. The afternoon westerly (onshore) wind component prevails from 0 to $500 \mathrm{~m}$ while the easterly (offshore) one appears between 500 and $1000 \mathrm{~m}$. At Paposo the separation of the breeze systems below and above $1000 \mathrm{~m}$ is especially clear.

The mean meridional wind component $(V)$ shows invariably northerlies above the MBL, in particular for Iquique and Paposo during VOCALS-REx, as also observed at Point Alpha at about $200 \mathrm{~km}$ off Iquique (Zheng et al., 2011; their Fig. 6). The ubiquitous northerly wind component at altitudes below the mean top of the Andes, gradually shifting to westerlies above the mean mountain top $(\sim 5000 \mathrm{~m})$, is presumably related to the blocking of the westerly flow components under thermodynamically stable conditions (i.e., small Froude numbers), with the subsequent formation of a barrier jet, as documented for central Chile (Rutllant and Garreaud, 2004). To further document this feature and its manifestation at different heights below the top of the Andes, Fig. 3 presents the 1961-1987 frequency distribution of wind directions at Antofagasta (Cerro Moreno Airport) as a function of height for 08:00 and 20:00 LT (Zamora, 2010). While southerlies are the most common winds in the MBL below 

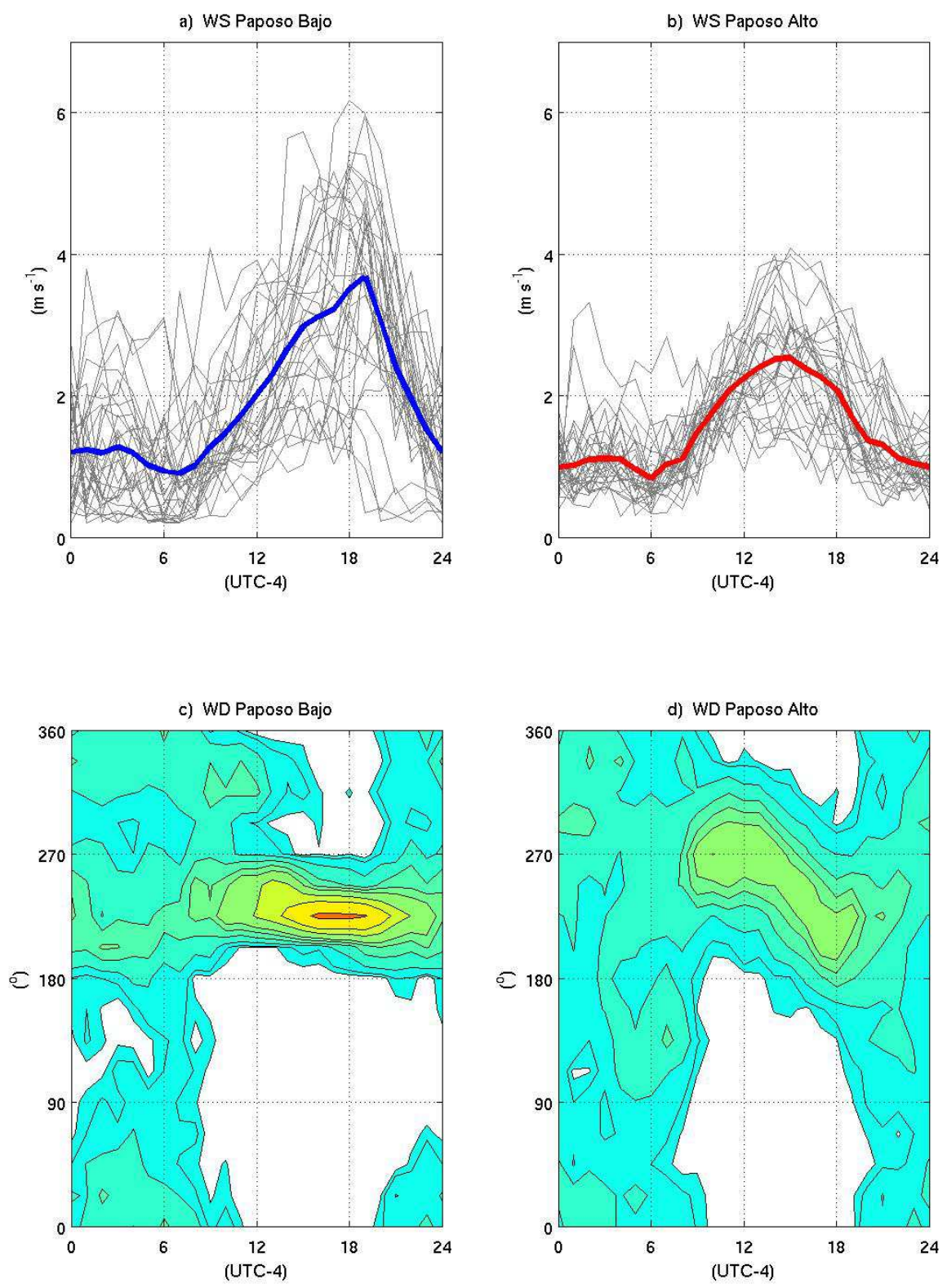

Fig. 4. (a) Diurnal cycle of wind speed at PB. Thin gray lines show daily series, the mean diurnal cycle in bold; (b) as (a) but for PA; (c) frequency of occurrence of wind directions throughout the day for PB, warmer colors depict higher frequencies; (d) as (c) but for PA.

$1000 \mathrm{~m}$ (especially in the afternoon soundings), northerlies prevail above it (more markedly in the morning soundings), at least up to $3000 \mathrm{~m}$ altitude, shifting gradually to westerlies above the Andes with increasing frequency up to the tropopause (not shown).

Mean diurnal cycles of surface winds at PB and PA (Fig. 4) show low speeds at nighttime and early morning of about $1 \mathrm{~m} \mathrm{~s}^{-1}$, with variable directions but with slightly higher frequency of N-NE at PB. Here, afternoon southwesterlies reach maximum mean speed and persistence at about 18:00 LT, while PA shows broader peaks in mean afternoon speeds $\left(\sim 2-3 \mathrm{~m} \mathrm{~s}^{-1}\right)$ and direction frequency (from the W) cen- tered at 15:00 LT. Time series and mean diurnal cycles of surface-based observations of air temperature, downwelling solar radiation, relative humidity/mixing ratio, winds and atmospheric pressure at PA and PB during the full VOCALSREx period are included for further studies in the Supplement.

\subsection{Afternoon increase in coastal subsidence}

The DICLIMA experiment (Rutllant et al., 2003) provided evidence in support of the hypothesis of an afternoon increase in subsidence along the coast and above the MBL 

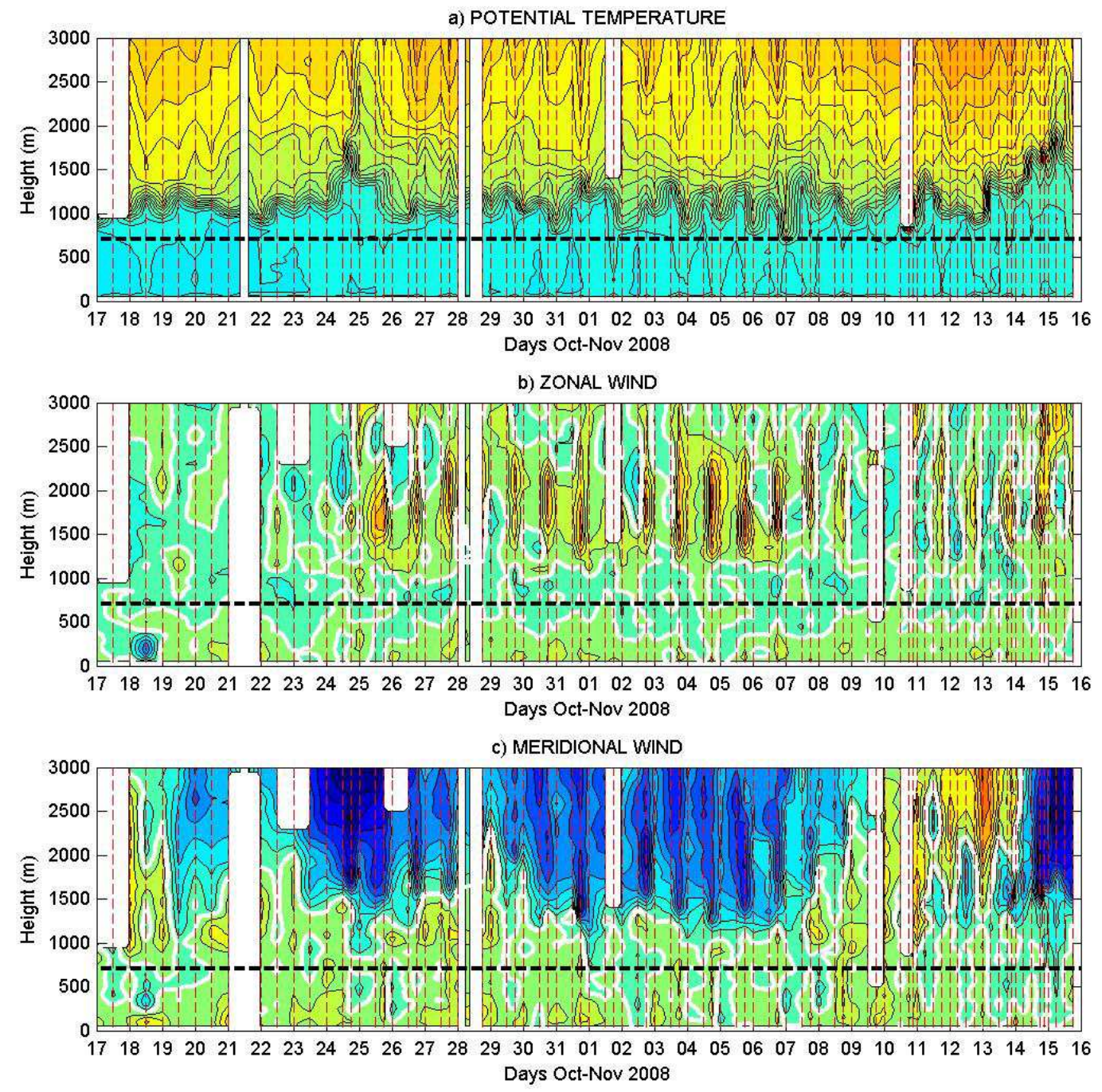

Fig. 5. Time-height cross sections of Paposo radiosonde observations during VOCAL-REx. (a) Potential temperature (contours every $2^{\circ}$ K), (b) zonal wind component (contours every $2 \mathrm{~m} \mathrm{~s}^{-1}$; white contour is $0 \mathrm{~m} \mathrm{~s}^{-1}$ ), (c) as (b) but for the meridional wind component. Horizontal black dashed lines mark the altitude of PA. Vertical red dashed lines mark times of available radiosonde launchings.

(Rutllant and Ulriksen, 1979, and references therein) due to divergence of the daytime upslope flow (Andean pumping). This extra coastal subsidence, ultimately related to the daytime solar heating of the western slope of the Andes, could help in explaining the warming near the inversion top and the slight descent of the subsidence inversion base in the afternoon (Rutllant et al., 2003).

The importance of the diurnal cycle of vertical velocity coupled with the thermal structure just above the subsidence inversion was addressed through a numerical model simulation by Muñoz (2008). There, coastal subsidence at $\sim 24-26^{\circ} \mathrm{S}$ maximizes between $2000-3000 \mathrm{~m}$ altitude with peak values at local noon, extending through the afternoon (Muñoz, 2008; his Fig. 12). Associated temperature tendency due to vertical advection amounted to $0.75 \mathrm{~K} \mathrm{~h}^{-1}$ produc- ing maximum warming at about 15:00 LT (Muñoz, 2008; his Fig. 11).

This warming is observed at Iquique and Michilla and, in a more diffuse way, at Paposo (Fig. 2). Mean diurnal cycles in temperature, from the right panels in Fig. 2, indicate maximum warming rates in the 1000-2000 $\mathrm{m}$ height range of magnitudes $\sim 1.5^{\circ} \mathrm{K}$ between 10:00 and 16:00 LT at Iquique and between 14:00 and 20:00 LT at Paposo. Differences in timing of the maximum subsidence among different locations along the coast within the VOCALS-REx area probably reflect the "upsidence wave" propagation described in Rahn and Garreaud (2010b; their Fig. 9). Around dawn, cooling at about the subsidence inversion base, noticeable at Paposo and Michilla, could be associated to radiative cooling at the top of the Sc cloud deck. 


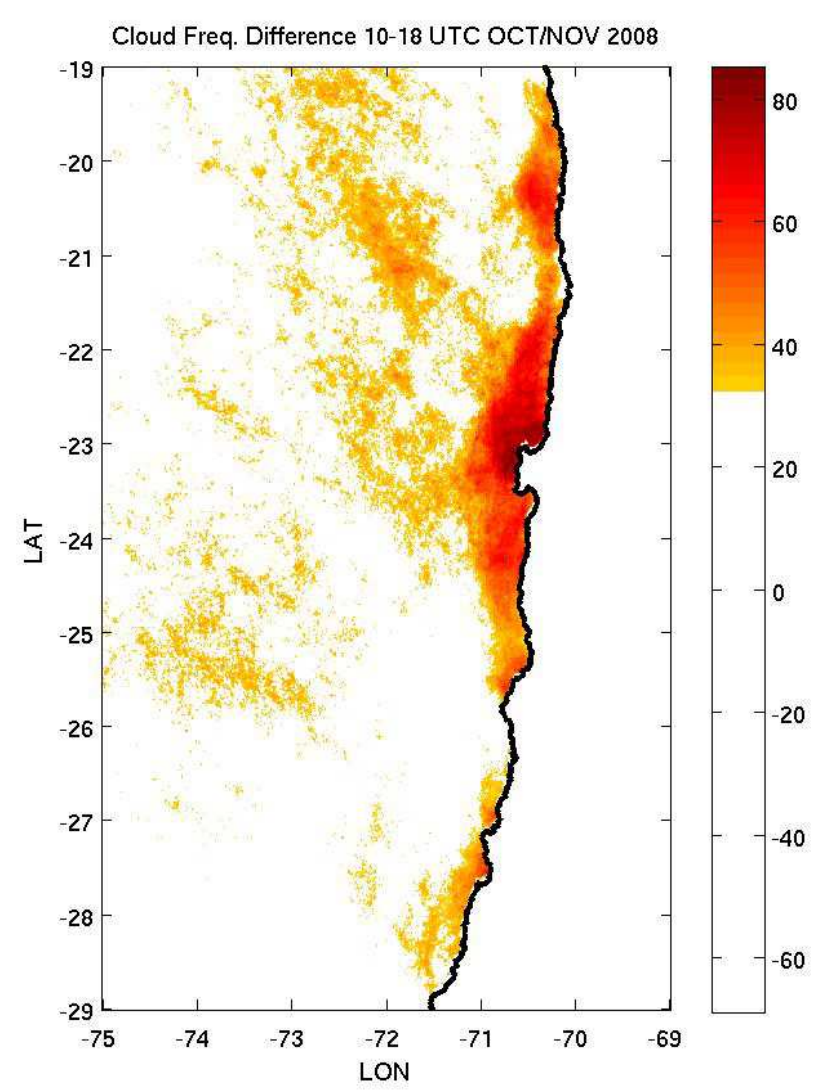

Fig. 6. Early morning (10:00 UTC) minus early afternoon (18:00 UTC) cloud frequency diagnosed from GOES visible imagery analysis for October-November 2008. A reflectivity threshold of $0.04(0.10)$ was used to distinguish between cloudy and clear pixels in the visible image closest to 10:00 UTC (18:00 UTC). Cloud frequency drops below $30 \%$ and over the continent have been masked out.

Except for the last 3 days in the VOCALS-REx period in which a cutoff low significantly deepened the coastal MBL, the height of the subsidence inversion base at 08:00 LT varied typically between 800 and $1200 \mathrm{~m}$ a.s.l. both at Paposo (Fig. 5a) and Antofagasta (not shown). At this latter site the range of variation falls very well in the long-term climatological distribution according to the results of Muñoz et al. (2011). The more frequent radiosoundings available at Paposo suggest the existence of a diurnal cycle in MBL height, with a mean decrease of $\sim 130 \mathrm{~m}$ between 14:00 and 20:00 LT (the perturbed final period excluded for this estimate). The afternoon clear coastal strip of about $50 \mathrm{~km}$ shown in Fig. 6, illustrating a climatological PM-AM Sc cloud frequency from GOES visible imagery, could be related to this afternoon depression of the MBL. In the following section, model diagnostics of the vertical motion are used to estimate vertical temperature advection in connection with the afternoon warming above the MBL and the afternoon descent of the base of the subsidence inversion.

\subsection{Numerical simulation of wind and temperature daily mean cycles}

To further document the afternoon increase in coastal subsidence resulting from the mean diurnal cycles of the zonal wind above the MBL and, in particular, its offshore extension and its connection with the afternoon warming in the coastal FT, a numerical simulation of the regional circulation with the Weather Research and Forecasting (WRF) model was performed for the first four days in November 2008, when atmospheric conditions remained fairly stationary (see Fig. 5). Mean diurnal cycles for the zonal and meridional wind components observed in the lower troposphere at Iquique and Paposo have been chosen to validate the WRF model output above the MBL. The relative magnitude and phase of the maximum afternoon zonal wind component at both locations (Fig. 2) are well captured by the model (Fig. 7), as well as the level and magnitude of the corresponding return flows. Differences between the stations in the phase and magnitude of the northerlies at about $3000 \mathrm{~m}$ are also well represented in the numerical results.

To describe the cross-shore, cross-mountain circulation, Fig. 8 represents $U$ and $W$ cross sections averaged over 19$22^{\circ} \mathrm{S}$, where the coastline and terrain contours run sensibly in a meridional direction (see Fig. 1) for (a) 17:00 to 19:00 LT, and (b) for 05:00 to 07:00 LT (averages of the 4day WRF run), representing the extremes of the mean diurnal cycle above the MBL. In the afternoon the Andean pumping from the coastal mountains inland (upslope flow) exceeds $5 \mathrm{~m} \mathrm{~s}^{-1}$ with a weak seaward return flow centered at about $750 \mathrm{hPa}$, in fair agreement with observations (Fig. 2), suggesting divergence over the coastal area (assuming $\partial \mathrm{V} / \partial \mathrm{y}$ $\sim 0$ ). At dawn there is a weak (less than $1 \mathrm{~m} \mathrm{~s}^{-1}$ ) downslope flow with a hint of zonal convergence above the coastline. This diurnally varying regional pattern is also in good agreement with the DICLIMA observations (Rutllant et al., 1998; their Fig. 8). Zooming into the coastal area, Fig. 9 depicts hourly changes in vertical velocity at $800 \mathrm{hPa}$, illustrating the onset of the subsidence increase at local noon and peaking between 13:00 and 17:00 LT in a narrow band less than $10 \mathrm{~km}$ wide. At around 20:00 LT there is a sudden change in vertical velocity from downward to upward motion, likely connected to the pass of the positive phase of the "upsidence wave" (Rahn and Garreaud, 2010b; their Fig. 9).

To further characterize the timing of the maximum coastal subsidence and associated warming, mean simulated diurnal cycles of vertical velocity and diurnal temperature anomalies $\left(T^{\prime}\right)$ with pressure, for the same days and latitudinal span as before, are shown for column $P$ (average coastal profile represented by a vertical dashed line in Fig. 8) in Fig. 10. There, the afternoon increase in subsidence centered at $\sim 800 \mathrm{hPa}$ is concurrent with maximum positive $T^{\prime}$ values $\left(\sim 1^{\circ} \mathrm{C}\right)$. Since the maximum afternoon subsidence from noon to 18:00 LT exceeds $2 \mathrm{~cm} \mathrm{~s}^{-1}$ at $800 \mathrm{hPa}$ and the potential temperature difference between $700 \mathrm{hPa}$ and $900 \mathrm{hPa}$ 

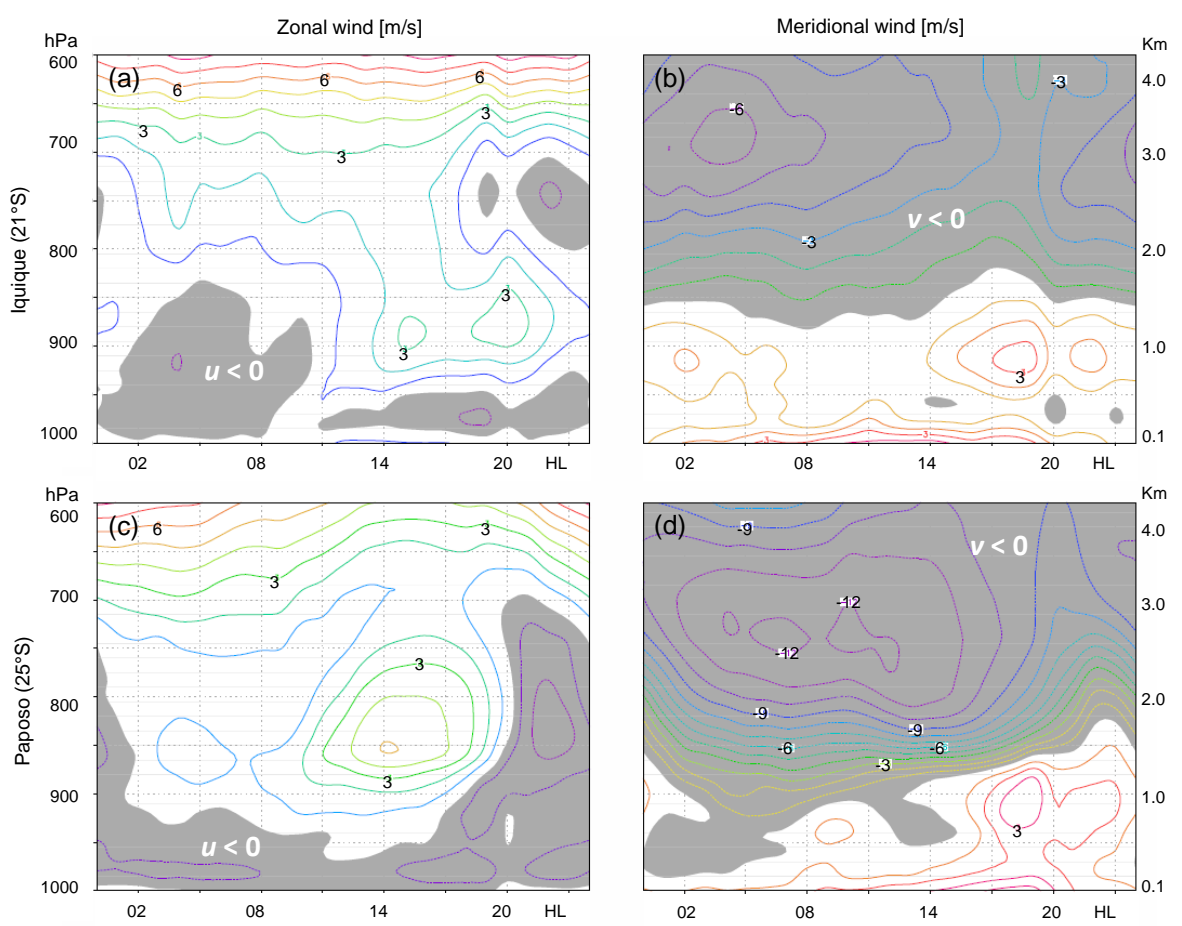

Fig. 7. WRF-simulated 4-day mean diurnal cycles at a coastal column at $21^{\circ} \mathrm{S}$ (near Iquique, upper panels) and $25^{\circ} \mathrm{S}$ (near Paposo, lower panels). Left panels: zonal wind component $\left(1 \mathrm{~m} \mathrm{~s}^{-1}\right.$ contours; the zero line is omitted and easterly flow in light gray). Right panels: meridional wind component $\left(1 \mathrm{~m} \mathrm{~s}^{-1}\right.$ contours; the zero line is omitted and northerly flow in light gray).

is $\sim 25 \mathrm{~K}$, the associated $6-\mathrm{h}$ warming due only to vertical temperature advection $(-\mathrm{W} \partial \theta / \partial \mathrm{z})$ is of the order of $5^{\circ} \mathrm{K}$, value that should be partially compensated by onshore cold advection when comparing with an observed 6-h temperature increase of $\sim 1.5^{\circ} \mathrm{K}$ (see Sect. 3.2). During the same time interval, the simulation diagnoses also a mean subsidence of about $1 \mathrm{~cm} \mathrm{~s}^{-1}$ at $900 \mathrm{hPa}$ yielding a descent of about $215 \mathrm{~m}$ in the subsidence inversion base that, considering the deepening effect of entrainment, compares favorably with the mean decrease of $\sim 130 \mathrm{~m}$ between 14:00 and 20:00 LT observed at Paposo (see Sect. 3.2).

Since assessment of potential aerosol transport to the Sc cloud deck from coastal and inland sources was a central motivation of this work, forward trajectories have been calculated using a simple advective scheme and the WRFsimulated mean diurnal 3-D wind field (4-day averages of $U, V, W)$. Three release locations (Fig. 11) at ground level were chosen to represent a coastal site near Iquique, an elevated source within the MBL (i.e., PA) and an inland source at about $3000 \mathrm{~m}$ altitude (e.g., an inland copper smelter). The released air parcels were followed for the next $24 \mathrm{~h}$. Figure 11 shows the parcel's location every $3 \mathrm{~h}$ superimposed on a topographic map. The strong daytime pumping of the Andes in combination with a much weaker return flow, together with a mild seasonal nocturnal easterly flow, preclude any possibility of continental sulfur sources to reach the Sc cloud deck in at least a one-day timescale, under mean conditions.
Within the MBL, some coastal sources could contribute with sulfur aerosols preferentially in the morning, provided that the weak daytime inland flow becomes partially blocked by the coastal terrain, following a mean northward path in the afternoon.

\subsection{Day-to-day variability in MBL depth, surface winds and sea-level pressure}

Toniazzo et al. (2011) describe large-scale conditions during VOCALS-REx: a weak La Niña in the central equatorial Pacific concomitant with a poleward expansion of the subtropical anticyclone. These authors point out that larger variability observed in the MBL depth in October 2008 was a consequence of enhanced midlatitude synoptic forcing. Lower and less variable inversion heights prevailed in early November due to baroclinic activity restricted to higher latitudes, increased subsidence associated with the onset of convective activity over the Altiplano (Bolivian High) and a favourable position (i.e., western equatorial Pacific) of the active phase of the Madden-Julian Oscillation (Toniazzo et al., 2011).

Alongshore-oriented coastal and inland mountain ranges, in combination with a quasi-permanent subsidence inversion frequently below the mean coastal mountains altitude within the study area, can sustain poleward-propagating wave-like phenomena whose pace is at least partially synchronized with synoptic-scale midlatitude, eastward-travelling troughs and 

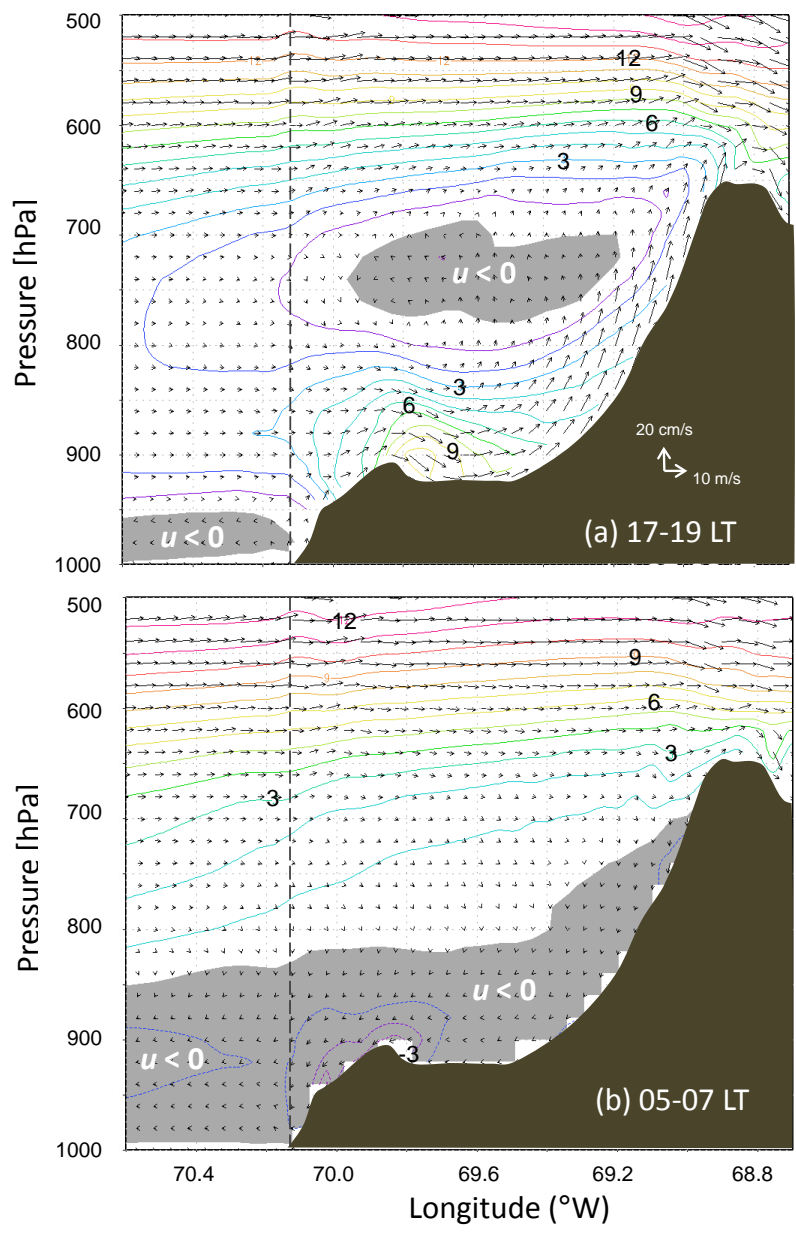

Fig. 8. WRF-simulated mean zonal $(U)$ - vertical $(W)$ wind vectors (arrows) in an average cross section between $19-22^{\circ} \mathrm{S}$ (where main topographic features run approximately north-south; see Fig. 1). Contours are zonal wind speeds: positive (solid) and negative (dashed) for (a) afternoon conditions (17:00-19:00 LT) and (b) dawn conditions (05:00-07:00 LT). Light gray areas indicate easterly flow; dark gray areas mark the topographic profile. The vertical dashed line represents the selected longitude for vertical profiles (column $P$ ) used later in Fig. 10.

ridges in the upper troposphere. Thus, amplitude and timing of diurnal cycles, including the depth of the MBL, are regularly modulated by sub-synoptic to synoptic-scale disturbances, the latter described and analyzed for the whole VOCALS-REx area in Rahn and Garreaud (2010b) (hereinafter referred to as $\mathrm{RG}$ ).

Day-to-day changes in the depth of the well-mixed MBL, represented as the height of the base of the subsidence inversion layer in a time-height cross section of potential temperature at PB (Fig. 5a), exhibit up and down excursions from a mean depth of $\sim 1000 \mathrm{~m}$. In a few occasions during the experiment, PA (dashed line in Fig. 5) was immersed in the warm, dry air on top of the clouds. In the period of decreased synoptic-scale forcing (e.g., 4-9 November) particular regu-

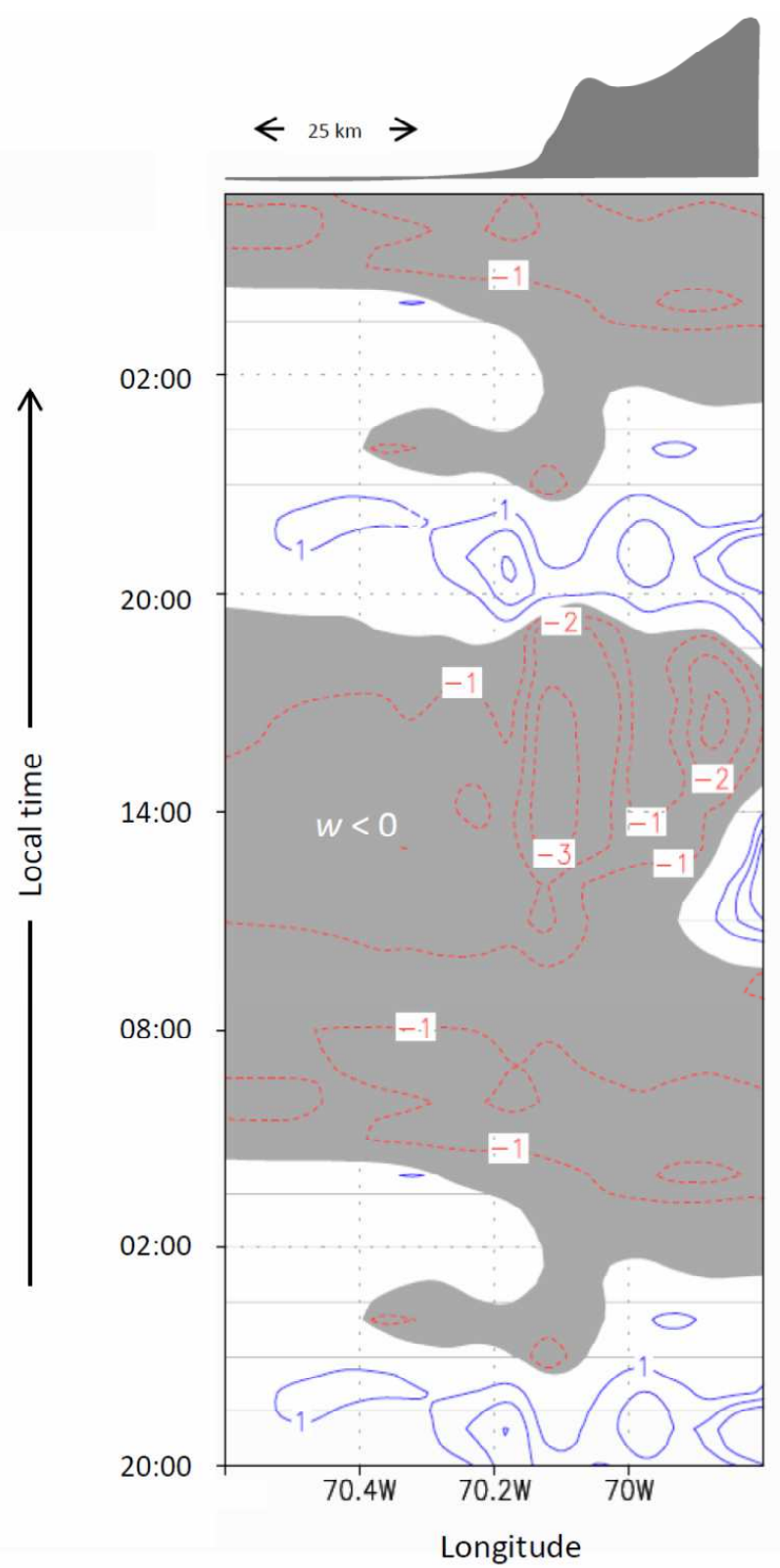

Fig. 9. Time-longitude cross section of WRF-simulated vertical velocity $\left(W, \mathrm{~cm} \mathrm{~s}^{-1}\right)$ at $800 \mathrm{hPa}$ averaged between $19-22^{\circ} \mathrm{S}$ and over the 4-day run. Positive values (upward motion) in blue, solid contours; negative values in red, dashed contours. Light shading indicates subsidence. For display purposes, part of the mean diurnal cycle is repeated. The dark gray area at top represents the average topographic profile.

lar diurnal cycles can be observed in the MBL depth, with minimum values reached late in the afternoon $(\sim 20: 00 \mathrm{LT})$, the lowest depth being reached on 7 November. Above the MBL, particularly regular north-westerlies prevailed (Fig. 5 $b, c)$. This period also features high diurnal ranges in nearsurface air temperature and relative humidity at both $\mathrm{PB}$ and PA, under mostly clear skies (Figs. S1, S2 and S3). 


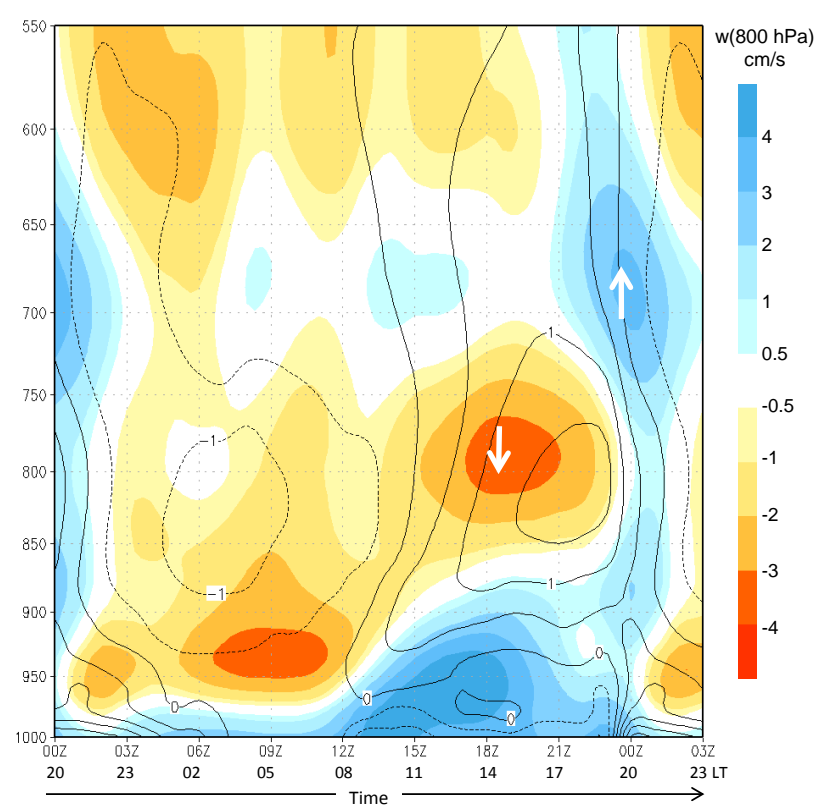

Fig. 10. Diurnal cycle of the vertical velocity (colors, in $\mathrm{cm} \mathrm{s}^{-1}$ ) and air temperature anomalies (contours: positive solid, negative dashed) with pressure at the coastal column $\mathrm{P}$ (see location in Fig. 8) averaged between $19-22^{\circ} \mathrm{S}$ and over the 4-day run. Cold colors indicate ascent, warm colors indicate subsidence. For display purposes, part of the mean diurnal cycle is repeated.

In connection with synoptic-scale disturbances, on the other hand, the MBL top rose sharply on 24 October and more gradually towards the end of the field experiment (1415 November). The latter condition occurred under the influence of a cutoff low (see RG). In fact, from 11-14 November SSE winds in the middle troposphere sharply veered to N-NW on 14-15 November (Fig. 5b, c). Concurrent with this wind reversal, ridging and warming of the middle troposphere since 6 November gave way to a sudden cooling on the 14 th.

To illustrate in more detail the synoptic-scale modulation of diurnal cycles at PB, an 8-day period beginning 24 October (T3 period in $\mathrm{RG}$ ) is depicted in Fig. 12. Under the well defined synoptic-scale forcing existing at the beginning of this period, the onset of a ridge in the mid-troposphere (Fig. 12a) in 25 October was followed by a decrease in the MBL depth (Fig. 12b), strengthening of the surface southerlies (Fig. 12c) and a rapid drop in SLP (sea level pressure) (Fig. 12d). After the minimum of SLP early on the 26th, the MBL depth recovers and the alongshore winds weaken. This pattern of co-variability between MBL depth, alongshore wind strength and SLP centered on the first SLP minimum closely resembles those described for Central Chile by Garreaud et al. (2002), Garreaud and Rutllant (2003), Rutllant and Garreaud (2004), and for the Antofagasta region by Rutllant et al. (1998, 2003). Conditions around the second SLP minimum in 29 October are more disturbed as we

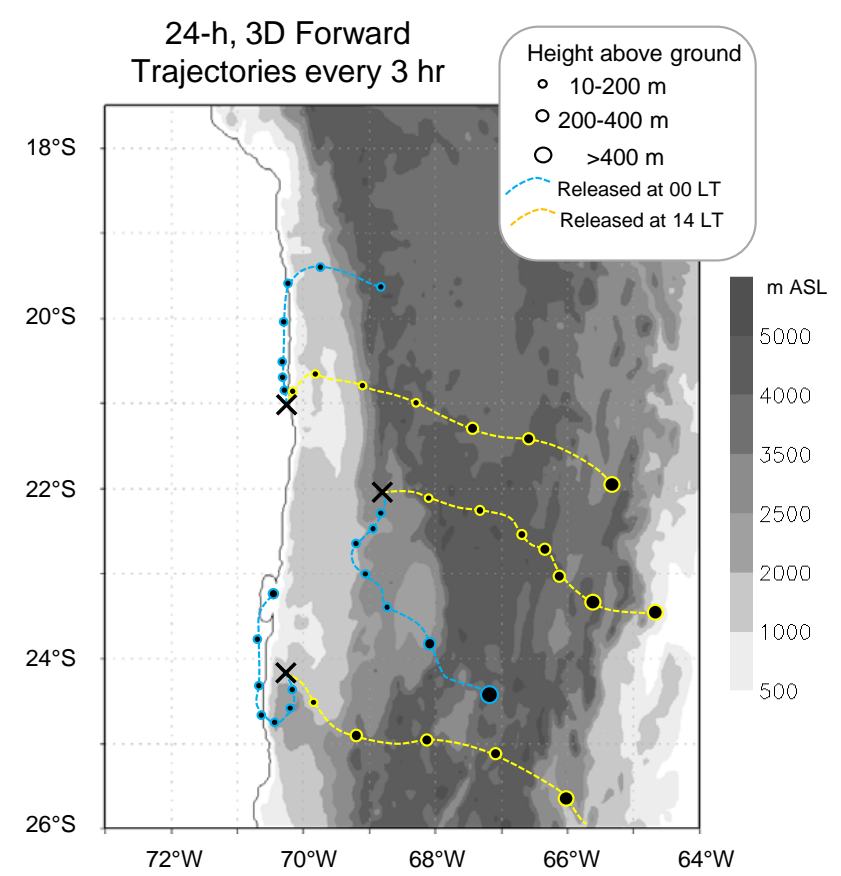

Fig. 11. Forward trajectories calculated using a simple advective scheme and the WRF-simulated diurnal mean (4-day average) three-dimensional wind field $(U, V, W)$. Three release locations were chosen (black crosses) and the parcels were followed for the next $24 \mathrm{~h}$. The figure shows the parcel's location every $3 \mathrm{~h}$ (circles) superimposed on a topographic map. The circle size indicates parcel height above terrain (see scale atop). Yellow (blue) symbols indicate the trajectories of parcels released at 14:00 LT (midnight).

enter the more stable period at the end of the month. However, maximum southerly speeds during decreasing SLPs and a concurrent slight decrease in the MBL depth are still there.

Over the whole study period, minimum MBL depths, with the subsidence inversion base marginally touching PA, occurred on 25 and 30 October, and on 3 and 6 November, with light NE winds and associated SLP minima (Fig. S4c). Simultaneous time series of 500 and $1000 \mathrm{hPa}$ geopotential heights simulated for the VOCALS region (RG, their Fig. 2a) show ridging at $500 \mathrm{hPa}$ and a simultaneous drop in $1000 \mathrm{hPa}$ heights. This results in high $1000-500 \mathrm{hPa}$ thicknesses, indicating easterly warm advection in the lower troposphere, as occurred on 10 and 26 October, and on 2 November. Low MBL depths in-between probably correspond to subsynoptic oscillations without any apparent midlatitude connection (Fig. 5a). These local/regional oscillations (2 to 4 day periods) in the MBL depth can be better identified in the radiosonde data from Iquique (not shown).

Near-surface maximum afternoon wind speeds around $6 \mathrm{~m} \mathrm{~s}^{-1}$ at PB occurred on 13-14, 20, 25, 27-29 October, and on 6-8 November (Fig. S4a). Near the end of these maximum wind speed occurrences in late October, minima in atmospheric pressure (Fig. S4c: 21, 22 and 29 October) were 

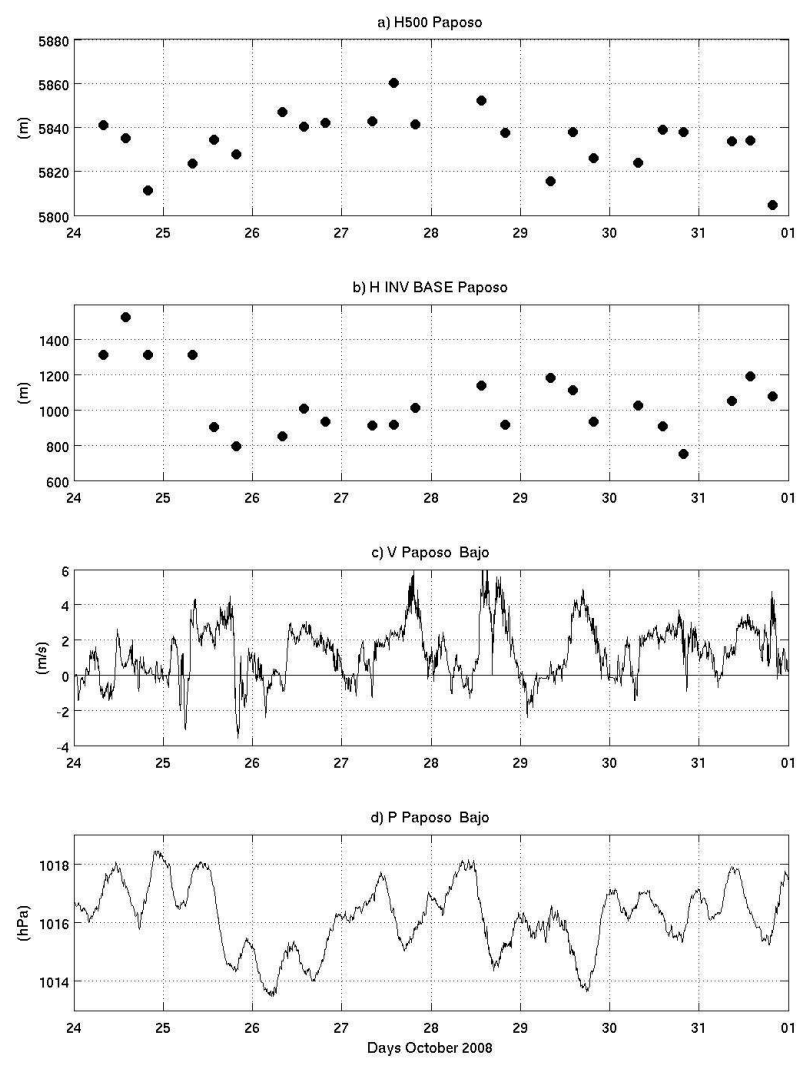

Fig. 12. Time series of (a) $500 \mathrm{hPa}$ geopotential height, (b) subsidence inversion base, (c) meridional wind speed, (d) atmospheric pressure at Paposo Bajo for the period from 24 to 31 October 2008.

also accompanied by enhanced NE warm advection (downslope flow) at early morning, resulting in low MBL depths.

Similar conditions as those described here have been reported by Huneeus et al. (2006) for strong easterly wind events at $700 \mathrm{hPa}$ (using Antofagasta radiosonde data) and by Velásquez (2010) while climatologically characterizing the synoptic patterns associated to the extremes in the MBL depth, also at Antofagasta.

\section{Summary}

Land-based surface and upper air meteorological observations during VOCALS-REx are analyzed together with model simulations in this, mostly descriptive, contribution under the motivation that mean diurnal circulation cycles within and above the marine boundary layer (MBL, with a mean depth of $\sim 1000 \mathrm{~m}$ ) could eventually play a role in transport from near shore and inland emissions to the offshore cloud-topped MBL in austral spring.

Within the coastal MBL sea-land breeze circulations are superimposed on the prevailing southerlies, resulting in light northeasterly winds from midnight to early morning and strong near-surface southwesterlies in the afternoon, with their corresponding return flows near the MBL top.

Above the MBL, a strong inland WSW afternoon flow between $1500 \mathrm{~m}$ and $2000 \mathrm{~m}$ peaks occurs at around the time of maximum solar warming over the Andes western slope. The weak seaward return flow is from the N-NE, peaking in the afternoon at about $3000 \mathrm{~m}$ altitude. At nighttime and early morning N-NE winds prevail at $\sim 1000-2500 \mathrm{~m}$ altitude, with an inland return flow from the N-NW at 2000 $4000 \mathrm{~m}$ altitude. Therefore, the prevailing flow from the $\mathrm{N}$ above the MBL and below the Andes top is modulated by the onshore-offshore (zonal) flow components of the regional circulation induced by the diurnal cycle of the radiative heating/cooling along the western slope of the Andes. A numerical simulation of the zonal atmospheric circulation in a regional domain from the ocean to the Andes $\left(19-22^{\circ} \mathrm{S}\right)$ captures the mean diurnal cycle of the winds above the MBL at Iquique and Paposo, and highlights the afternoon mean zonal wind divergence and the resulting subsidence of about $2 \mathrm{~cm} \mathrm{~s}^{-1}$ at around $800 \mathrm{hPa}$ along a narrow $(\sim 10 \mathrm{~km})$ coastal strip. Vertical temperature advection and subsidence partially explain the observed afternoon warming and descent of the subsidence inversion base.

From 24-h forward trajectories issued from significant points at the coast and inland at the extremes of the diurnal cycle, it can be concluded that the strong mean daytime Andean pumping prevents any possibility of continental sulfur sources reaching the free troposphere above the $\mathrm{Sc}$ cloud deck in at least a one-day timescale, under mean conditions. Conversely, coastal sources could contribute with sulfur aerosols preferentially in the morning, when the weak inland flow becomes partially blocked by the coastal terrain.

Day-to-day variability during VOCALS-REx shows 2 to 4-day oscillations in the MBL depth, aside from two major disruptions on 24 October in connection with a deep trough and a cutoff low on 14-15 November, as described in Rahn and Garreaud (2010b). These oscillations in the MBL tend to be closely connected to sea-level pressure and to the strength of the afternoon alongshore southerlies, in a coastal low-like scheme as found farther south (e.g., Garreaud et al., 2002).

\section{Supplementary material related to this article is available online at: http://www.atmos-chem-phys.net/13/ 3409/2013/acp-13-3409-2013-supplement.pdf.}

Acknowledgements. We want to thank here all the participants in the field work at Paposo, including personnel from the Chilean Weather Service (DMC) who took care of radiosonde launchings at PB. Radiosondes were kindly provided by Bruce Albrecht. Special thanks are also due to Ana María Córdova for general coordination at the Paposo site. We are also grateful for the facilities granted by the Paposo public school and by the National Forestry Corporation 
(CONAF) at Paposo Alto. Alejandra Molina kindly compiled the reflectivity fields used in the construction of Fig. 6. Support for the meteorological field work at Paposo was provided by the Department of Geophysics, Universidad de Chile. The NCAR Earth Observatory Laboratory provided field logistics and data archival of Iquique radiosoundings. We are also indebted to the Editor and two anonymous Reviewers who significantly contributed to the improvement of the manuscript. Garreaud acknowledges support by Project CONICYT/FONDAP/15110009.

Edited by: R. Weller

\section{References}

Abel, S. J., Walters, D. N., and Allen, G.: Evaluation of stratocumulus cloud prediction in the Met Office forecast model during VOCALS-REx, Atmos. Chem. Phys., 10, 10541-10559, doi:10.5194/acp-10-10541-2010, 2010.

Allen, G., Coe, H., Clarke, A., Bretherton, C., Wood, R., Abel, S. J., Barrett, P., Brown, P., George, R., Freitag, S., McNaughton, C., Howell, S., Shank, L., Kapustin, V., Brekhovskikh, V., Kleinman, L., Lee, Y.-N., Springston, S., Toniazzo, T., Krejci, R., Fochesatto, J., Shaw, G., Krecl, P., Brooks, B., McMeeking, G., Bower, K. N., Williams, P. I., Crosier, J., Crawford, I., Connolly, P., Allan, J. D., Covert, D., Bandy, A. R., Russell, L. M., Trembath, J., Bart, M., McQuaid, J. B., Wang, J., and Chand, D.: South East Pacific atmospheric composition and variability sampled along $20^{\circ} \mathrm{S}$ during VOCALS-REx, Atmos. Chem. Phys., 11, 5237-5262, doi:10.5194/acp-11-5237-2011, 2011.

Bretherton, C. S., Uttal, T., Fairall, C. W., Yuter, S. E., Weller R. A., Baumgardner, D., Comstock, K., Wood, R., and Raga, G. B.: The EPIC 2001 Stratocumulus Study, B. Am. Meteorol. Soc., 85, 967-977, 2004.

Chand, D., Hegg, D. A., Wood, R., Shaw, G. E., Wallace, D., and Covert, D. S.: Source attribution of climatically important aerosol properties measured at Paposo (Chile) during VOCALS, Atmos. Chem. Phys., 10, 10789-10801, doi:10.5194/acp10-10789-2010, 2010.

Figueroa, D. and Moffat, C.: On the influence of topography in the induction of coastal upwelling along the Chilean coast, Geophys. Res. Lett., 27, 3905-3908, 2000.

Garreaud, R. and Muñoz, R.: The low-level jet off the west coast of subtropical South America: structure and variability, Mon. Weather Rev., 133, 2246-2261, 2005.

Garreaud R. and Rutllant, J.: Coastal Lows along the Subtropical West Coast of South America: Numerical Simulation of a Typical Case, Mon. Weather Rev., 131, 891-908, 2003.

Garreaud R., Rutllant, J., Fuenzalida. H.: Coastal Lows along the Subtropical West Coast of South America: Mean Structure and Evolution, Mon. Weather Rev., 130, 75-88, 2002.

Garreaud, R. D., Rutllant, J. A., Muñoz, R. C., Rahn, D. A., Ramos, M., and Figueroa, D.: VOCALS-CUpEx: the Chilean Upwelling Experiment, Atmos. Chem. Phys., 11, 2015-2029, doi:10.5194/acp-11-2015-2011, 2011.

González C., Rutllant, J., and Paolini, P.: Frecuencia y Albedo de Estratocúmulos Costeros entre $24-32^{\circ} \mathrm{S}$, Cuarto Taller Circulación Océanica y Atmosférica en el Pacífico SE (DOCA), Dirección Meteorológica de Chile, Santiago, Chile, 18-19 Octubre 2007, 2007.
Huneeus, N., Gallardo, L., and Rutllant, J.: Offshore transport episodes of anthropogenic sulfur in northern Chile: Potential impact on the stratocumulus cloud deck, Geophys. Res. Lett., 33, L19819, doi:10.1029/2006GL026921, 2006.

Muñoz, R.: Diurnal cycle of surface winds over the subtropical Southeast Pacific, J. Geophys. Res., 113, D13107, doi:10.1029/2008JD009957, 2008.

Muñoz R., Zamora, R., Rutllant, J.: The coastal boundary layer at the eastern margin of the South East Pacific $\left(23.4^{\circ} \mathrm{S}, 70.4^{\circ} \mathrm{W}\right)$ : cloudiness conditioned climatology, J. Climate, 24, 1013-1033, 2011.

Painemal, D., Garreaud, R., Rutllant, J., and Zuidema, P.: Southeast Pacific Stratocumulus: High Frequency Variability and Mesoscale Structures over San Félix Island, J. Appl. Meteorol. Clim., 49, 463-477, 2010.

Rahn, D. A. and Garreaud, R.: Marine boundary layer over the subtropical southeast Pacific during VOCALS-REx - Part 2: Synoptic variability, Atmos. Chem. Phys., 10, 4507-4519, doi:10.5194/acp-10-4507-2010, 2010a.

Rahn, D. A. and Garreaud, R.: Marine boundary layer over the subtropical southeast Pacific during VOCALS-REx - Part 1: Mean structure and diurnal cycle, Atmos. Chem. Phys., 10, 4491-4506, doi:10.5194/acp-10-4491-2010, 2010b.

Rutllant J. and Garreaud, R.: Episodes of strong flow down the western slope of the subtropical Andes, Mon. Weather Rev., 132, 611-622, 2004.

Rutllant J. and Ulriksen, P.: Boundary-Layer Dynamics of the extremely arid northern part of Chile: The Antofagasta Field Experiment, Bound.-Lay. Meteorol., 17, 41-55, 1979.

Rutllant J., Fuenzalida, H., Torres, R., and Figueroa, D.: Interacción océano atmósfera tierra en la región de Antofagasta (Chile, $22^{\circ} \mathrm{S}$ ): Experimento DICLIMA, Rev. Chil. Hist. Nat., 71, 405427, 1998.

Rutllant J., Fuenzalida, H., and Aceituno, P.: Climate dynamics along the arid northern coast of Chile: The 19971998 Dinámica del Clima de la Región de Antofagasta (DICLIMA) experiment. J. Geophys. Res.-Atmos., 108, 4358, doi:10.1029/2002JD003357, 2003.

Saide, P. E., Spak, S. N., Carmichael, G. R., Mena-Carrasco, M. A., Yang, Q., Howell, S., Leon, D. C., Snider, J. R., Bandy, A. R., Collett, J. L., Benedict, K. B., de Szoeke, S. P., Hawkins, L. N., Allen, G., Crawford, I., Crosier, J., and Springston, S. R.: Evaluating WRF-Chem aerosol indirect effects in Southeast Pacific marine stratocumulus during VOCALS-REx, Atmos. Chem. Phys., 12, 3045-3064, doi:10.5194/acp-12-3045-2012, 2012.

Spak, S. N., Mena, M., and Carmichael, G.: Atmospheric transport of anthropogenic oxidized sulfur over the Southeast Pacific during VOCALS REx, CLIVAR Exchanges, 15, 20-21, 2010.

Sun, F., Hall, A., and Qu, X.: On the relationship between low cloud variability and lower tropospheric stability in the Southeast Pacific, Atmos. Chem. Phys., 11, 9053-9065, doi:10.5194/acp-119053-2011, 2011.

Toniazzo, T., Abel, S. J., Wood, R., Mechoso, C. R., Allen, G., and Shaffrey, L. C.: Large-scale and synoptic meteorology in the south-east Pacific during the observations campaign VOCALSREx in austral Spring 2008, Atmos. Chem. Phys., 11, 49775009, doi:10.5194/acp-11-4977-2011, 2011.

Velásquez, P. A.: Patrones sinópticos asociados a la variabilidad de la capa límite marina en Antofagasta, Chile, Undergraduate 
Thesis, Universidad de Valparaíso, Chile, 2010.

Yang, Q., Gustafson Jr., W. I., Fast, J. D., Wang, H., Easter, R. C., Wang, M., Ghan, S. J., Berg, L. K., Leung, L. R., and Morrison, H.: Impact of natural and anthropogenic aerosols on stratocumulus and precipitation in the Southeast Pacific: a regional modelling study using WRF-Chem, Atmos. Chem. Phys., 12, 87778796, doi:10.5194/acp-12-8777-2012, 2012.

Wang, S., O’Neill, L. W., Jiang, Q., de Szoeke, S. P., Hong, X., Jin, H., Thompson, W. T., and Zheng, X.: A regional real-time forecast of marine boundary layers during VOCALS-REx, Atmos. Chem. Phys., 11, 421-437, doi:10.5194/acp-11-421-2011, 2011.

Wood, R., Mechoso, C. R., Bretherton, C. S., Weller, R. A., Huebert, B., Straneo, F., Albrecht, B. A., Coe, H., Allen, G., Vaughan, G., Daum, P., Fairall, C., Chand, D., Gallardo Klenner, L., Garreaud, R., Grados, C., Covert, D. S., Bates, T. S., Krejci, R., Russell, L. M., de Szoeke, S., Brewer, A., Yuter, S. E., Springston, S. R., Chaigneau, A., Toniazzo, T., Minnis, P., Palikonda, R., Abel, S. J., Brown, W. O. J., Williams, S., Fochesatto, J., Brioude, J., and Bower, K. N.: The VAMOS Ocean-Cloud-Atmosphere-Land
Study Regional Experiment (VOCALS-REx): goals, platforms, and field operations, Atmos. Chem. Phys., 11, 627-654, doi:10.5194/acp-11-627-2011, 2011.

Zamora, R.: Observational characterization of the marine boundary layer in Antofagasta, M.S. thesis, Dept. of Geophysics, University of Chile, 122 pp., 2010 (in Spanish).

Zheng, X., Albrecht, B., Jonsson, H. H., Khelif, D., Feingold, G., Minnis, P., Ayers, K., Chuang, P., Donaher, S., Rossiter, D., Ghate, V., Ruiz-Plancarte, J., and Sun-Mack, S.: Observations of the boundary layer, cloud, and aerosol variability in the southeast Pacific near-coastal marine stratocumulus during VOCALSREx, Atmos. Chem. Phys., 11, 9943-9959, doi:10.5194/acp-119943-2011, 2011. 